\title{
Utilizing Rice Husk Briquettes in Firing Crucible Furnace for Low Temperature Melting Metals in Nigeria
}

\author{
Nicholas Akhaze Musa \\ Department of Mechanical Engineering \\ Auchi Polytechnic, Auchi \\ Edo State, Nigeria \\ Madonick1@yahoo.com
}

\author{
Folorunsho Olayiwola Akinbode \\ Department of Mechanical Engineering \\ University of Abuja \\ Abuja, Nigeria
}

\begin{abstract}
The search for alternative fuels for firing crucible furnace for low temperature melting metals has become mandatory, as a result of the pollution problem associated with the use of fossil fuels, the expense of electricity and also deforestation as a result of the use of charcoal. An agricultural waste, rice husk, in briquette form was used as an alternative fuel to fire crucible furnace to melt lead, zinc and aluminium. Results showed that lead and zinc melted and reached their pouring temperatures of $3840 \mathrm{C}$ and $5300 \mathrm{C}$ in 70 minutes and 75 minutes respectively. Aluminium was raised to a maximum temperature of $5200 \mathrm{C}$ in 75 and 100 minutes. The average concentration of the pollutants (CO, SO2and NOX) were found to be below the tolerance limit and that of TSP (Total Suspended Particulates) was found to be within the tolerance limit stipulated by Federal Environmental Protection Agency (FEPA) in Nigeria.
\end{abstract}

Keyword:s rice husk briquettes; lead; zinc; aluminium; furnace.

\section{INTRODUCTION}

Traditionally, coal was used as solid fuel for firing melting furnace. However, it is hardly suitable because of its sluggish response to temperature control, the large space required for storage and associated health hazards [1]. In Nigeria, especially in the rural areas, charcoal is widely used to fire non-ferrous melting furnace. These charcoals are produced from wood. The increase in demand for wood for the production of charcoal and other uses has caused a lot of deforestation. If the trend is not kept under control, Nigeria will be depleted of wood at the expense of natural ecological settings.

Electricity is regarded as a clean energy source. However, the generation of electricity requires the use of energy from renewable and non-renewable sources, some of which are not environmentally friendly. In the operation of solid fuel (coal), fuel oil and gas fired furnaces, carbon dioxide, carbon monoxide, sulphur dioxide, oxides of nitrogen and TSP. These gases have adverse effect on both humans and the environment [2].

Fossil fuels are also used for other purposes, for example in the manufacture of goods such as plastics or chemicals for agriculture and animal food stuff [3]. The increased use of fossil fuels leads gradually to their depletion. Apart from the depletion and the environmental problem of the fossil fuel, the procurement cost is very high and this has adverse effect on the industries where non-ferrous products are produced. The problems of fossil fuels depletion, environmental pollution and high procurement cost are being dealt with in various ways. These include, among others, energy conservation and the search for alternative fuel sources that are environmentally friendly, available to all and sundry.

Agricultural waste is one of such alternative energy sources. Rice husk, being such a waste, is thoroughly generated especially in rural areas of the country. Rice husk has been used in loose form to supplement firewood for cooking, but with loss of fuel and pollution. In order to enhance its use the briquette form can be used. The rice husk briquettes has been investigated by many researchers. Notable among them are, Permchart and Tenatvanit in [4], Krongkaew, Jurgen and Christian in [5], Musa in [6], and Bhattacharya et al in [7].Their results revealed the potential use of such briquettes in firing cooking and heating devices. The comparison of the use of traditional fuel to rice husk briquettes in terms of availability and quantities required, cost of the fuel etc are discussed as follows:

\section{A. Availability and Quantities Required.}

Traditional fuels such as diesel, liguefied petroleum gas (LPG) are not readily available in Nigeria, as a result of diversion and irregularities being practiced by marketers. Coal resources have been estimated to be 2.5 billion tonnes, but there is no serious effort by the Government for their exploitation. The annual wood consumption in Nigeria is about 88 million cubic meters and $80 \%$ is utilized as fuel (charcoal and fuelwood). The charcoal and fuelwood are readily available but the consumption rate exceeds the replenishment rate.

From preliminary study, about 20.3 liters of diesel, $2.88 \mathrm{~kg}$ of LPG, $22.4 \mathrm{~kg}$ of charcoal and $21.18 \mathrm{~kg}$ of coal are required to individually fire melting furnace to melt $12 \mathrm{Kg}$ each of Lead, Zinc and Aluminium in cottage industries in Nigeria. 
The land mass used for rice cultivation in Nigeria is about 1.8 million hectares. Recently the quantity of rice produced was about 1900470.14 tonnes and 1520262.23 tonnes were milled as revealed by the National Cereal Research Institute (NCRI). The high quantity of rice husk generated can be estimated to be 168918.03 tonnes. When made into briquettes, such an amount will result in large quantities. In this work, the quantity required to fire the furnace to individually melt $12 \mathrm{~kg}$ each of Lead, Zinc and Aluminium is to be estimated.

\section{B. Cost of the Fuel}

The cost of diesel, LPG, charcoal and coal in Nigeria are $\$ 120$ per liter, $\$ 285$ per $\mathrm{Kg}, \$ 125$ per $\mathrm{Kg}$ and $\$ 135$ per $\mathrm{Kg}$. The rice husk briquettes cost $\$ 15$ per $\mathrm{Kg}$.

\section{Time Required to Attain the Required Temperature}

From preliminary study, the time required by diesel, LPG, charcoal and coal to reach the required combustion temperatures are 50, 45, 65 and 60 minutes respectively. Rice husk briquettes are expected to reach their combustion temperature in a longer period.

\section{Temperature Requirement}

Similarly, from preliminary survey, the combustion temperature requirement of Diesel, LPG, charcoal and coal are $1701^{\circ} \mathrm{C}, 1782^{\circ} \mathrm{C}, 1110^{\circ} \mathrm{C}$, and $1360^{\circ} \mathrm{C}$ respectively.

\section{E. Labour Utilization}

Using diesel or LPG is less labor intensive because the fuel can be loaded at once. But using charcoal, coal and rice husk briquettes, requires periodical loading, especially in case of small furnaces, and evacuation of ash.

Further use of rice husk briquettes in firing crucible furnace for low temperature melting metals, is the aim of this study, with a view to find alternatives to other conventional fuel in firing melting furnace.

\section{MATERIALS AND METHOD}

\section{A. Materials and Equipment}

50.5 kilogram of cylindrical rice husk briquettes with an average density of $524 \mathrm{~kg} / \mathrm{m}^{3}$ and compaction pressure of $1471.5 \mathrm{KW} / \mathrm{m}^{3}$ were used to fire the furnace. The following equipment was used to carry out various tests:

- Non-ferrous melting furnace designed and constructed for this purpose.

- Weighing scales (manufactured in China by Dapeng)

- Gas alert micro and sample analyser (manufactured in Canada by B.W Technologies Ltd).

- Gaztell Portable toxic gas monitors ( supplied by ELE International, England)

- Type -K- thermocouple, (manufactured in China by Nigbo Taisuo Tech. Ltd
- Stop watch

- Nose mask

B. Types and composition of low melting metals (nonferrous) selected for study

- $\quad$ Lead $(\mathrm{Pb})-99.97 \%(\mathrm{~Pb}), 0.03 \%$ impurity level by weight

- $\quad$ Zinc (Zn) - 99.99\% (Zn), 0.01\% impurity level by weight

- $\quad$ Aluminium (Al) - 99.59\% (Al), (Cu), 0.04\% (Fe), 0.34 (Si)

\section{Experimental Procedure}

$12 \mathrm{~kg}$ of each of the test samples (lead, zinc and aluminium, were put in individual crucible. One of the crucibles containing one of the $12 \mathrm{~kg}$ of the test sample is shown in Figure 1.

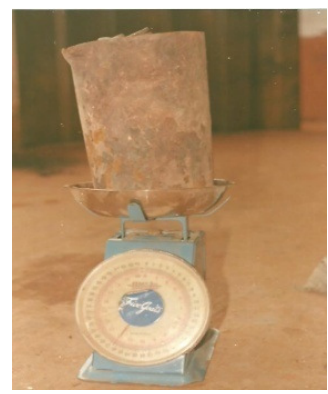

Fig. 1. A crucible containing lead sample.

These crucibles were individually put in the furnace. A thermocouple probe was inserted in the crucible to measure the melting temperature of the test samples. Three type Kthermocouple probes were positioned on a $340 \mathrm{~mm}$ diameter, spaced at $120^{\circ}$ in the combustion chamber of the furnace, to measure the combustion temperature. The average of the temperature recorded by the three thermocouples, at a time was taken as the combustion temperature of the briquettes. This was in line with the works of Grant in [8]. Another type Kthermocouple probe was inserted in the chimney, to measure the flue gas temperature. The furnace was loaded with individual briquettes. Ignition was initiated by arranging waste paper between the briquettes and lit with a match stick. An air flow valve was gradually opened. Figure 2 shows the crucible furnace being fired with rice husk briquettes.

Rice husk briquettes were used to fire the crucible furnace to melt lead, zinc and aluminium individually. The loading schedule for the crucible furnace is shown in Table 1 . The frequencies of loading were determined by the number of periods, the briquettes in the furnace got combusted with sudden drops in combustion temperature and melting temperature of the non-ferrous metal.

Temperature readings viz-a-viz melting temperature of the test samples, combustion temperature, and the flue gas temperature were taken in five minutes interval. The 
concentration of $\mathrm{CO}$ and $\mathrm{SO}_{2}$ were measured with Gas alert micro sample analyzer (manufactured in Canada by BW technologies ltd) and the concentration of $\mathrm{NO}_{\mathrm{X}}$ was measured with Gaztell portable toxic gas monitor, with the probes inserted in the exhaust pipe. The manometric deflection of the U-tube manometer fitted to the exhaust pipe were read and used to determine the flue extraction rates. Adopting Akeredolu and Oyawale method as described in [9], a re-weighed $2 \mu \mathrm{m}$ cellulose filter paper was held in place by a filter holder to trap the particulate matter. This was re-weighed in five minutes interval during the test period. The TSP was estimated by the product of the extraction rates and the weight of the particulate matter. All the readings were carried out in an interval of five minutes. After each operation, the furnace was evacuated. The duration of the test depended on the time needed for the melting temperature to fall within the range of the pouring temperatures of individual non-ferrous. For aluminium whose melting and pouring temperatures could not be reached, the test was terminated after 150 minutes.

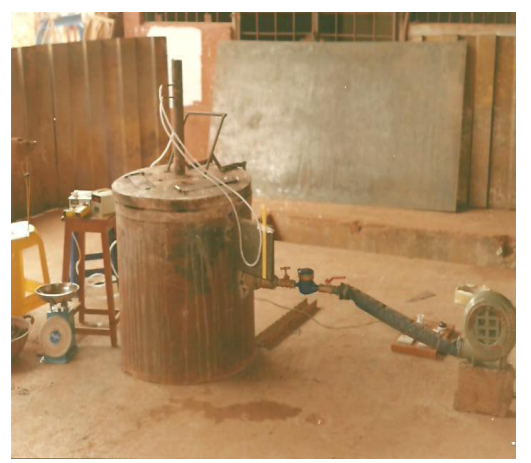

Fig. 2. The furnace being fired with rice husk briquette samples

TABLE I. SCHEDULE FOR RICE HUSK BRIQUETTES LOADING OF THE FURNACE

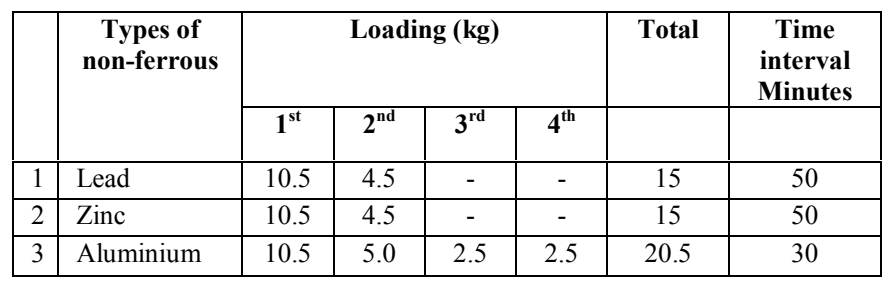

III. RESULTS AND DISCUSSION

The variations of combustion, melting, flue gas temperatures with time and the average measured concentrations of the pollutants from rice husk briquettes fired furnace for melting lead, zinc and aluminium respectively, are shown in Figures 3, 4 and 5 and Table 2 respectively.

It can be seen from Figures 3, 4 and 5 that the combustion temperature increased with the heating temperature of the non ferrous metals, lead, zinc and aluminium, as well as the temperature of the flue gas.

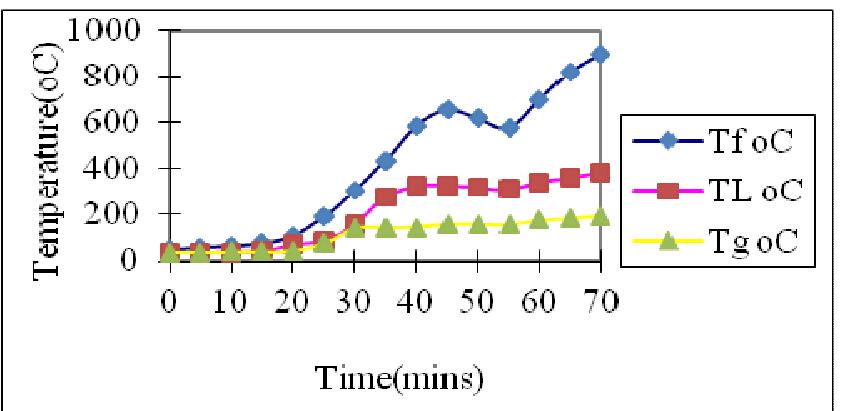

Fig. 3. Variation of combustion, lead melting and flue gas temperature (Tf, TL and Tg) with time using rice husk briquettes.

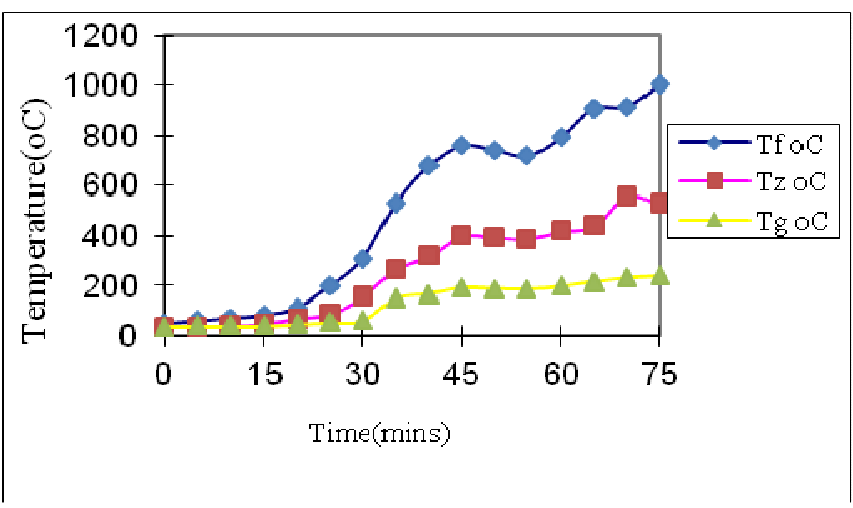

Fig. 4. Variation of flame, Zinc melting and flue gas temperature (Tf, Tz and $\mathrm{Tg}$ ) with time using rice husk briquettes.

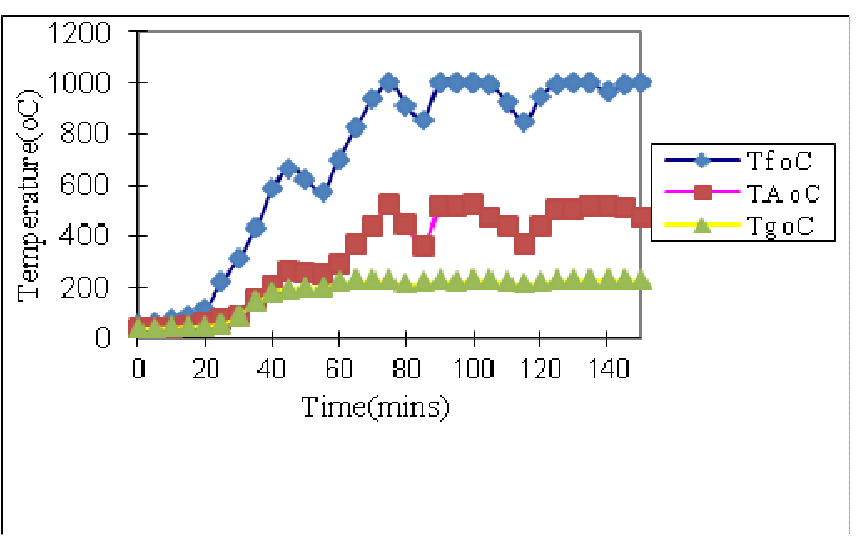

Fig. 5. Variation of combustion, Aluminium melting and flue gas temperature (Tf, TA and $\mathrm{Tg}$ ) with time using rice husk briquettes.

The increase in temperature was low in the early stages of combustion, that is between 0 and 15 minutes, which was the smoldering stage. The increase in temperature was high in the later stages of the combustion, that is between 20 and 45 minutes for lead, 25 and 45 minutes for zinc, 20 and 45 minutes for aluminium. Drops in combustion, melting and flue gas temperatures were experienced between 50 and 55 minutes for lead and zinc, 50 and 55 minutes, 80 and 85 minutes, 105 and 115 minutes, 135 and 140 minutes for aluminium. This could be attributed to an uneven combustion process of solid 
fuel and refueling of the furnace with the briquettes at those periods, where there were transitions from the flaming stage to the smoldering stage. However, the furnace fired with rice husk briquettes was able to melt lead and zinc in 40 and 60 minutes respectively, and bring them to their respective pouring temperature of $384^{\circ} \mathrm{C}$ and $530^{\circ} \mathrm{C}$ in 70 and 75 minutes. It could only raise the temperature of aluminium to a maximum temperature of $521^{\circ} \mathrm{C}$ in 75 and 100 minutes.

$15 \mathrm{Kg}, 15 \mathrm{Kg}$ and $20.5 \mathrm{Kg}$ of briquettes were respectively used to attain a temperature of $1000^{\circ} \mathrm{C}$ for 70 minutes as shown in Figure 1, 75 minutes as shown in Figure 2 and 140 minutes as shown in Figure 3.

In 0 minutes, no emission of $\mathrm{SO}_{2}, \mathrm{NO}_{\mathrm{X}}$ and TSP occured. It should be noted that, at that time, combustion was just initiated. It was after 20 minutes that emissions of $\mathrm{NO}_{\mathrm{X}}$ were experienced. However, the emission of $\mathrm{NO}_{\mathrm{X}}$ was due to the oxidation of the nitrogen present in the briquettes and not atmospheric nitrogen, because the later oxidizes when the furnace temperature is about $1500^{\circ} \mathrm{C}$ [10]. The furnace or combustion temperature of the rice husk briquette was found to be less than $1500^{\circ} \mathrm{C}$.

In a nutshell, as the temperature of combustion, melting metal and flue gas increased with time, emissions of $\mathrm{SO}_{2}$ and $\mathrm{NO}_{\mathrm{X}}$ also increased with time. But the emissions of $\mathrm{CO}$ and TSP decreased with time.

These values of the average concentrations of $\mathrm{CO}, \mathrm{SO}_{2}$ and $\mathrm{NO}_{\mathrm{X}}$ as depicted in Table 2, were found to be below the environmental tolerance limit of $10-20 \mathrm{ppm}$ for $\mathrm{CO}, 0.01$ $0.1 \mathrm{ppm}$ for $\mathrm{SO}_{2}$ and $0.04-0.06 \mathrm{ppm}$ for $\mathrm{NO}_{\mathrm{X}}$. The values of the average concentration of the TSP estimated shown in Table 2, was found to be within the limit of $0.2-0.6 \mathrm{mg} / \mathrm{m}^{3}$ stated by Federal Environmental Protection Agency of Nigeria.

TABLE II. AVERAGE MEASURED CONCENTRATIONS OF THE POLLUTANTS FROM RICE HUSK BRIQUETTE FIRED CRUCIBLE FURNACE.

\begin{tabular}{|l|l|l|l|l|}
\hline & \multicolumn{4}{|c|}{ Concentration of pollutants } \\
\hline $\begin{array}{c}\text { Types of } \\
\text { melted } \\
\text { Non- } \\
\text { ferrous }\end{array}$ & CO (ppm) & $\begin{array}{c}\mathbf{S O}_{\mathbf{2}} \\
(\mathbf{p p m})\end{array}$ & $\begin{array}{c}\mathbf{N O} \mathbf{X}_{\mathbf{X}} \\
(\mathbf{p p m})\end{array}$ & $\begin{array}{c}\mathbf{T S P} \\
\left(\mathbf{g} / \mathbf{m}^{\mathbf{3}}\right)\end{array}$ \\
\hline Lead & 7.3 & 0.08 & 0.014 & 0.00051 \\
\hline Zinc & 7.0 & 0.081 & 0.015 & 0.00055 \\
\hline Aluminium & 6.4 & 0.079 & 0.0135 & 0.00051 \\
\hline
\end{tabular}

\section{CONCLUSION}

The quantities of the briquettes used were sufficient but the heat released from the burning of the briquettes perhaps was not enough to melt aluminium whose melting and pouring temperatures are far higher than those of lead and zinc considered in this study.

However, rice husk briquettes can be used to fire crucible furnace to melt low temperature melting metals such as lead, zinc and any other metal whose melting points and pouring temperatures are lower. It can also be used to preheat aluminium to about $531^{\circ} \mathrm{C}$.
The use of rice husk briquettes in firing crucible furnace for low temperature melting metals is environmentally friendly, partly solves the disposal problem, and serves as good alternative to other conventional fuel.

\section{REFERENCES}

[1] H. A. Monks, D. Rochester, Technician metallurgical process technology 2. Macmillan publishing Co. Inc, 1980

[2] N. K. Giri, Automobile technology, Khanna Publishers, 2004

[3] T. D. Eastop, A. McConkey Applied Thermodynamics for Engineering Technologist. Longman publishers, 1993

[4] W. Permchart, S. Tenatvanit, "Preliminary investigation on combustion characteristics of rice husk in FBC", World Academy of Science, Engineering and Technology, Vol. 56, pp. 183-186, 2009

[5] L. Krongkaew, H. Jurgen, W. Christian , "The production of synthetic diesel from biomass", KMITL Science Technology Journal. Vol. 6, No 1, pp. 35-45, 2006

[6] N. A. Musa, "Full characteristics of some selected Biomass Briquettes" Internationa Journal of Science and Technology Research. Vol. 6, No 4, pp. 24-28, 2006

[7] S. C. Bhattacharya, A. H. Md, M. Siddique, L. Augustus, H. C. Pham, C. P Mahandari, "A study on improved institutional biomass stoves", Asian Institute of Technology Journal, pp. 1-6, 2001

[8] B. T. Grant, Emissions of rural wood burning cooking devices. PhD Thesis Faculty of Engineering University of the Witwatersrand Johannesburg, 1997

[9] F. A. Akeredolu, O. C. Oyawale "Monitoring combustion chamber", Journal of the Nigerian Society of Chemical Engineers, pp. 10-12, 2000

[10] P. K. Nag, Power Plant Engineering, Tata McGraw-Hill publishing Company Ltd, 2001 